\title{
Het Effect van Hormoonbehandeling op het Emotioneel Welzijn en het Cognitief Functioneren van Transmannen
}

\author{
Renske Mocking ${ }^{1,2}$, Remi Soleman $^{2,3}$, Hessel Engelbregt ${ }^{1,4}$ \\ ${ }^{1}$ Hersencentrum Amsterdam \\ ${ }^{2}$ Vrije Universiteit Amsterdam, Afdeling Gedrags- en Bewegingswetenschappen, Sectie \\ Klinische Neuropsychologie \\ ${ }^{3}$ Amsterdam UMC, Afdeling Medische Psychologie, Kennis- en Zorgcentrum voor \\ Genderdysforie \\ ${ }^{4}$ Ludwig-Maximilian Universiteit, München, Duitsland
}

\author{
Correspondentieadres \\ renskemocking@hotmail.com
}

\section{Samenvatting}

Transmannen zijn geboren met een vrouwelijk lichaam maar identificeren zich gevoelsmatig als man. In de huidige studie werd de invloed van hormoontherapie op het emotioneel welzijn en het cognitief functioneren van transmannen nagegaan. In het onderzoek participeerden 22 transmannen, en een controlegroep van 20 vrouwen en een van 19 mannen. De transmannen ontvingen gedurende 8 weken een voorbehandeling met een $\mathrm{GnRH}$-analoog waarna als basismeting een testbatterij werd afgenomen. De testbatterij bestond uit vragenlijsten voor het meten van het emotioneel welzijn en bevatte tevens neuropsychologische testen om een aantal cognitieve vaardigheden te onderzoeken. Voor het meten van het emotioneel welzijn werden de Hospital Anxiety and Depression Scale (HADS) en de Symptom Checklist (SCL-90) gebruikt. De SCL-90 bestaat uit de subschalen Angst, Agorafobie, Depressie, Somatische klachten, Insufficiëntie van denken en handelen, Wantrouwen en interpersoonlijke sensitiviteit, Hostiliteit en Slaapproblemen. Na de 8 weken voorbehandeling kregen de transmannen 16 weken testosteron (met daarnaast een GnRH-analoog en een aromataseremmer) toegediend. Hierna werd opnieuw dezelfde testbatterij afgenomen. De controlegroepen ontvingen gedurende het gehele onderzoek geen interventie. Bij alle onderzoeksgroepen werd op dezelfde momenten de testbatterij afgenomen. Verwacht werd dat de hormoonbehandeling een (positief of negatief) effect zou hebben op het emotioneel welzijn (depressie, angst en psychologische symptomen) van de transmannen. Daarnaast werd verwacht dat het cognitieve profiel van de transmannen als gevolg van de hormoonbehandeling zou verschuiven van een relatief 'vrouw-typisch' cognitief profiel (sterke verbale vaardigheden) naar een 'man-typisch' cognitief profiel (sterk ruimtelijk inzicht). Met betrekking tot executief functioneren en verbaal geheugen werd geen invloed verwacht en ten aanzien van verwerkingssnelheid was het onderzoek exploratief. De resultaten laten geen verandering zien in het emotioneel welzijn ten gevolge van de 
hormoontherapie. De resultaten konden ook niet alle verwachte cognitieve effecten bevestigen. Het vermoeden dat hormoontherapie geen invloed zou hebben op het executief functioneren en het verbale geheugen van de transmannen werd wel bevestigd in deze studie. Tot slot werd tegen de verwachting in geen effect gevonden van de hormoontherapie op snelheid van de informatieverwerking. Wel gaven de resultaten van de SCL-90 aan dat transmannen gemiddeld hogere scores hadden op de slaap- en hostiliteitsschaal dan vergelijkingsgroepen van vrouwen en mannen. Vervolgonderzoek naar de verschillen tussen transpersonen en controlegroepen en de invloed van hormoonbehandeling op emotioneel welzijn en cognitief functioneren is noodzakelijk om de transgenderzorg indien nodig te verbeteren.

Sleutelwoorden: transmannen, hormoonbehandeling, emotioneel welzijn, cognitieve functies

\section{Definitie transgender}

De meeste westerse culturen gaan uit van een binaire classificatie van gender: iemand is of vrouw of man [1]. Bij deze opvatting wordt uitgegaan van een overeenkomst tussen het bij geboorte toegewezen geslacht en de genderidentiteit van een persoon. Het geslacht wordt bij de geboorte doorgaans door een arts toegekend [2] op basis van het biologische genotype en fenotype [3]. Genderidentiteit verwijst naar het vrouw of man zijn dat iemand gevoelsmatig ervaart $[2,3]$. Het omvat onder andere de identiteit, het gedrag en de presentatie van de desbetreffende persoon, ongeacht of deze eigenschappen overeenkomen met het toegewezen geslacht [4].

Tussen dit 'toebedeelde' geslacht en de genderidentiteit van een persoon kan incongruentie bestaan, zoals het geval is bij transgender personen die incongruentie ervaren met hun toegekende geslacht [5, 6]. Dit kan gepaard gaan met lijdensdruk. Benadrukt moet worden dat ook personen die geen genderbevestigende behandeling hebben ondergaan transgender genoemd kunnen worden [7, 8].

\section{Transgenderprevalentie}

Tussen 1995 en 2009 hebben in totaal 900 transgender personen via de rechtbank hun geslachtswijziging vastgelegd [9]. Hiervan was ongeveer $38 \%$ transman en $62 \%$ transvrouw. Op basis van deze cijfers concludeerde Kuyper [10] dat de prevalentie van transgender personen in Nederland neerkomt op 1:18.300. Tussen het prevalentiecijfer genoemd door Kuyper [10] en de prevalentiecijfers genoemd in het artikel van Eklund, Gooren en Bezemer [11] worden enkele overeenkomsten gevonden. Eklund et al. constateerden op basis van de cijfers van het Centraal Bureau voor de Statistiek van het destijds enige hormoontherapie-behandelcentrum voor transgender personen in Nederland (Academisch Ziekenhuis Vrije Universiteit), dat de prevalentie in 1986 van transmannen 1:54.000 was en van transvrouwen 1:18.000 was. Vermeld moet worden dat de cijfers van Eklund et al. gebaseerd zijn op data uit 1986 en derhalve verouderd zijn.

Meer recente data geven aan dat de aanmeldingen voor genderbevestigende behandeling in Nederland enorm is toegenomen. Het aantal mensen dat per jaar werd beoordeeld van 1972 tot december 2015 bij het genderteam van het Vumc blijkt 20-voudig vermeerderd van 34 in 1980 tot 686 in 2015. De geschatte prevalentie in Nederland in 2015 was 1:2.800 voor transvrouwen en 1:5.200 voor transmannen [12]. 


\section{Transgenderbehandeling}

Grossman en D'Augelli [1] rapporteren dat de transgenderrespondenten in hun onderzoek gemiddeld 10.4 jaar oud waren toen zij merkten dat hun genderidentiteit niet overeenkwam met hun toegewezen geslacht. Zij waren gemiddeld 13.5 jaar oud toen zij zich realiseerden dat andere mensen hen labelden als transgender, en ongeveer één jaar later identificeerden zij zichzelf als een transgender. Onderzoek van Schlatterer et al. [13] geeft aan dat psychiatrische problemen veel voorkomen bij transgender personen. Dit kan een gevolg zijn van de incongruentie die transgender personen ervaren met hun toegewezen geslacht.

Safer en Tangpricha [14] beschrijven behandelingsopties voor transgender personen die hulp wensen. Het minst invasief is psychologische begeleiding. Omdat deze begeleiding vaak niet leidt tot een vermindering van de gevoelens van genderincongruentie bestaan er behandelingsopties die het lichaam van de desbetreffende persoon zodanig aanpassen dat dit (beter) aansluit bij de ervaren genderidentiteit. Hormonen toedienen is hier een voorbeeld van. Aangezien in het huidige onderzoek gekeken werd naar transmannen, ligt de nadruk hier op deze groep. Transmannen zijn personen die het vrouwelijk geslacht toegewezen hebben gekregen bij de geboorte maar die zichzelf identificeren als man [15]. Bij deze groep werd in ons onderzoek de geslachtshormoonproductie onderdrukt door middel van een hormoonremmer (een GnRH-analoog) en werden het hormoon testosteron en een aromataseremmer toegediend. Testosterontoediening staat centraal in het transitieproces van transmannen en zorgt onder andere voor een lagere stem, mannelijke lichaamshaargroei en de vorming van fysiek mannelijke contouren [3, 16-18].
Toediening van de hormoonremmer 'GnRH-analoog' (Gonadotropin Releasing Hormone- analoog) verlaagt het luteïniserend- en follikelstimulerend hormoonniveau en daarmee de geslachtshormoonproductie [19]. De aromataseremmer blokkeert de omzetting van androgeen in oestrogeen [20, 21], zodat de activerende effecten van oestrogeen werden tegengegaan.

\section{Emotionele behandeleffecten}

De bovengenoemde behandelmethode heeft echter tevens effect op de emotionele staat van de desbetreffende persoon $[3,16$, 22]. De fysieke veranderingen die voortkomen uit de hormoontherapie gaan meestal gepaard met verbeteringen van het mentale en emotionele welzijn van de transgender persoon [3, 23]. Zo bleek in een onderzoek van Davis en Meier [16] dat therapie met testosteron een positief effect heeft op gevoelens van angst, depressie en woede van behandelde transmannen. Tevens vonden Gómez-Gil et al. [24] dat transgender personen die hormoontherapie ondergingen minder angst, depressie en sociale problemen ervoeren. Tot slot vonden Gorin-Lazard et al. [25] dat de hormoontherapie een positief effect had op de kwaliteit van leven en rapporteerden Murad et al. [26] stabielere relaties, verbetering van aanpassingsvermogen, algemene tevredenheid en psychisch welzijn.

In tegenstelling tot deze positieve effecten van hormoontherapie vonden Van Goozen, Cohen-Kettenis, Gooren, Frijda en Van de Poll [27] geen positieve stemmingsveranderingen bij transgender personen tijdens een behandelduur van 3 maanden. 


\section{Cognitieve behandeleffecten Ruimtelijk inzicht en verbale vaardigheden}

Veelvuldig onderzoek is gedaan naar sekseverschillen in cognitieve vaardigheden, vooral naar het verschil in 'ruimtelijk inzicht' en 'verbale vaardigheden'. Zo wordt gesteld dat mannen beter ruimtelijk inzicht hebben en vrouwen verbaal sterker zijn [28-30].

Voor deze bewering op het vlak 'ruimtelijk inzicht' is veel ondersteuning gevonden. In onderzoek presteerden mannen over het algemeen beter dan vrouwen op testen die ruimtelijk inzicht meten [31-33].

Silverman et al. suggereerden dat dit voortkomt uit het verschil in testosteronlevel tussen mannen en vrouwen. In hun onderzoek vonden zij namelijk een positief verband tussen testosteronlevels en spatiële taken. Silverman et al. beargumenteerden daarom dat mannen betere spatiële vaardigheden bezitten dan vrouwen aangezien mannen over het algemeen hogere testosteronlevels hebben.

Slabbekoorn, Van Goozen, Megens, Gooren en Cohen-Kettenis [34] vonden dat toegediend testosteron het ruimtelijk inzicht van transmannen vergrootte en dat dit zelfs kon uitstijgen boven het ruimtelijk inzicht van transvrouwen (bij geboorte toegewezen mannen) die nog geen hormoontherapie hadden ontvangen. Wat betreft verbale vaardigheden zijn onderzoeksresultaten niet eenduidig. Weiss et al. [30] vonden dat vrouwen in het algemeen beter presteerden dan mannen op verbale testen, zoals lexicale verbale vloeiendheid. In het reviewartikel van Wallentin [35] werd echter geen prestatieverschil tussen mannen en vrouwen gevonden met betrekking tot het verbale vermogen. Hij concludeerde dat meisjes enkel in de vroege taalontwikkeling op verbaal vlak in het voordeel zijn, maar dit voordeel verdwijnt naarmate zij ouder worden.

Tussen verbale vaardigheden en hormoontherapie bij transgender personen lijkt wel een duidelijk verband. In die zin dat er een afname is in verbale vloeiendheid na een hormoonbehandeling bij de transmannen [27].

\section{Executieve functies, geheugen en informatieverwerking}

Executieve functies worden gedefinieerd als het vermogen om een probleem oplossende programmering te handhaven zodat een doel behaald kan worden [36]. Een voorbeeld hiervan is 'shifting'. Onder 'shifting' wordt het vermogen verstaan om van aandacht te wisselen tussen verschillende (sub)taken [37]. Dit is essentieel voor het voltooien van taken in het dagelijks leven.

Op gebied van 'shifting' is nog veel onbekend met betrekking tot transgender personen en de effecten van hormoontherapie.

Wat betreft geheugen vonden Gómez-Gil et al. [38] dat testosteron een positief effect heeft op het visuele geheugen van transmannen, maar niet op het verbale geheugen.

Kimura [39] vond dat vrouwen op het gebied van verbaal geheugen over het algemeen beter presteren dan mannen. Het is mogelijk dat vrouwen inderdaad beter scoren dan mannen zoals Kimura [39] suggereerde, maar dat dit sekseverschil niet samenhangt met testosteron, maar met een andere factor. In dat geval is het verklaarbaar waarom het aanpassen van het testosteronlevel in het onderzoek van Gómez-Gil et al. [38] geen effect had op het verbaal geheugen, maar is het tevens verklaarbaar waarom vrouwen beter 
scoorden dan mannen in het onderzoek van Kimura [39]. Geconcludeerd kan worden dat mogelijk niet testosteron maar een alternatieve component verantwoordelijk is voor de afname in het verbale geheugen bij transmannen.

Camarata en Woodcock [40] vonden dat vrouwen beter zijn dan mannen in taken die de verwerkingssnelheid meten, ofschoon Roivainen [41] aangaf dat dit niet in alle onderzoeken naar voren komt. Aangezien het neuropsychologische domein 'verwerkingssnelheid' belangrijk is voor vele cognitieve vaardigheden, is het van belang om het effect van hormoontherapie op de verwerkingssnelheid van transgender personen na te gaan.

\section{Huidig onderzoek}

In deze studie werd gekeken naar 'emotioneel welzijn' en 'cognitief functioneren' van transmannen. Verwacht werd dat er een positieve of negatieve verandering in de emotionele staat van de transmannen zou optreden ten gevolge van de hormoonbehandeling, zowel in depressie, angst als in andere kenmerken van emotioneel welzijn.

Ten tweede werd gekeken naar eventuele veranderingen in cognitief functioneren. Verwacht werd dat er een positieve verandering in de 'man-typische' cognitieve functie 'ruimtelijk inzicht' zou optreden en een negatieve verandering in 'vrouw-typische' cognitieve vaardigheid 'verbale vaardigheden'. Met betrekking tot 'shifting' en 'verbaal geheugen' werd geen invloed verwacht en ten aanzien van 'verwerkingssnelheid' was het onderzoek exploratief. Zie voor een overzicht Tabel 1.

\section{Methode}

\section{Participanten}

Het huidige onderzoek maakt deel uit van een groter onderzoek naar het effect van hormoontherapie op transgender personen. De data zijn verkregen van transgender personen van het Kennis- en Zorgcentrum voor Genderdysforie (KZcG), Amsterdam UMC (locatie VUmc). Een inclusiecriterium voor deelnemers, in dit geval transmannen, was een 'genderdysforie' diagnose. Bovendien was er een mannelijke en een vrouwelijke controlegroep welke geworven waren op de campus van de Vrije Universiteit Amsterdam door gebruik te maken van flyers. De vrouwen dienden een menstruatiecyclus te hebben van maximaal 35 dagen en mochten de 3 maanden voorafgaand aan het onderzoek geen hormonale anticonceptie gebruikt hebben. Het ooit ontvangen hebben van een behandeling met geslachtshormonen werd gezien als een exclusiecriterium. Ten slotte mochten zowel de transmannen als de proefpersonen uit de controlegroepen geen psychische, neurologische of endocriene stoornissen hebben. Voor deelname aan het onderzoek was geschreven toestemming nodig. Het onderzoek was goedgekeurd door de Medische Ethische Toetsingscommissie van het VU Medisch Centrum in Amsterdam.

In totaal namen er 61 proefpersonen deel, i.e. 22 transmannen, 20 vrouwen en 19 mannen. De gemiddelde leeftijd van de transmannen was 22.42 jaar $(\mathrm{SD}=6.85$ jaar), van de vrouwen 25.63 jaar $(\mathrm{SD}=$ 6.18 jaar) en van de mannen 27.72 jaar $(\mathrm{SD}=3.94$ jaar). Demografische gegevens zijn weergegeven in Tabel 2. 
Tabel 1

Overzicht onderzoeksvragen

\begin{tabular}{lll}
\hline Onderwerp & Domein & Verwachte effect van de hormoonbehandeling \\
\hline Emotioneel & Depressie & Verandering (positief of negatief) in depressieve \\
welzijn & Angst & gevoelens \\
& $\begin{array}{l}\text { Psychologische } \\
\text { symptomen }\end{array}$ & $\begin{array}{l}\text { Verandering (positief of negatief) in angstgevoelens } \\
\text { Veranderingen (positief of negatief) met betrekking } \\
\text { tot psychologische symptomen }\end{array}$ \\
& & Verbeterd ruimtelijk inzicht \\
Cognitieve & Ruimtelijk inzicht & Verslechterde verbale vaardigheden \\
functies & Verbale vaardigheden & Geen verandering \\
& Shifting & Geen verandering \\
& Verbaal geheugen & Verandering in verwerkingssnelheid \\
& Verwerkingssnelheid &
\end{tabular}

Tabel 2

Demografische gegevens

\begin{tabular}{|c|c|c|c|c|}
\hline & $\begin{array}{l}\text { Totale } \\
\text { steekproef }\end{array}$ & Transmannen & Vrouw & Man \\
\hline Aantal (\%) & $61(100.0 \%)$ & $22(36.1 \%)$ & $20(32.8 \%)$ & $19(31.1 \%)$ \\
\hline Leeftijd M (SD) & $25.12(6.17)$ & $22.42(6.85)^{*}$ & $25.63(6.18)$ & $27.72(3.94)$ \\
\hline Minimum/maximum & $17.50 / 43.30$ & $17.50 / 43.30$ & $18.80 / 42.70$ & $19.90 / 33.60$ \\
\hline \multicolumn{5}{|l|}{ Hoogst afgeronde opleiding (\%) } \\
\hline Basisonderwijs & $5.0 \%$ & $14.3 \%$ & $0.0 \%$ & $0.0 \%$ \\
\hline Middelbaar onderwijs (VMBO, MAVO) & $15.0 \%$ & $38.1 \%$ & $0.0 \%$ & $5.3 \%$ \\
\hline Middelbaar beroepsonderwijs (MBO) & $10.0 \%$ & $9.5 \%$ & $0.0 \%$ & $21.0 \%$ \\
\hline Voortgezet onderwijs (HAVO, VWO) & $25.0 \%$ & $28.5 \%$ & $30.0 \%$ & $15.8 \%$ \\
\hline Hoger beroepsonderwijs ( $\mathrm{HBO}$ ) & $13.3 \%$ & $4.8 \%$ & $20.0 \%$ & $15.8 \%$ \\
\hline Wetenschappelijk onderwijs (WO) & $31.7 \%$ & $4.8 \%$ & $50.0 \%$ & $42.1 \%$ \\
\hline
\end{tabular}

* Significant lagere leeftijd van Transmannen alleen in vergelijking met mannen $(p=.015)$

De data werd geanalyseerd met behulp van de 'Statistical Package for Social Sciences' (SPSS, versie 24.0). 


\section{Materiaal}

Afnameduur van de testbatterij was 1 uur. Voorafgaand aan het afnemen van de testbatterij werden van alle proefpersonen demografische gegevens verzameld (zie Tabel 2). Daarnaast werd tijdens de testmomenten bloed afgenomen om de hormoonlevels (testosteron, oestrogeen, luteïniserend hormoon en follikel stimulerend hormoon) te bepalen. Van deze bepalingen werd gebruikt gemaakt bij 'functional magnetic resonance imaging' onderzoek naar de effecten van gonadale onderdrukking op hersenactiviteit bij deze groep transmannen [19].

\section{Vragenlijsten}

Voor het meten van het emotioneel welzijn en psychische klachten zijn de Hospital Anxiety and Depression Scale (HADS) en de Symptom Checklist (SCL-90) gebruikt.

De HADS is een zelfevaluatie-instrument en bestaat uit 14 items; 7 items die Depressie en 7 items die Angst meten. De vragen worden beantwoord door middel van een 4-punts Likert-schaal. Een hoge somscore op de subschalen indiceert een sterke aanwezigheid van depressie en/of angstklachten [42].

De SCL-90 is een multidimensionale klachtenlijst die de desbetreffende persoon zelf invult. Deze vragenlijst meet psychische en lichamelijke klachten en bestaat uit acht subschalen: Angst, Agorafobie, Depressie, Somatische klachten, Insufficiëntie van denken en handelen, Wantrouwen en interpersoonlijke sensitiviteit, Hostiliteit en Slaapproblemen. De totaalscore meet 'Psychoneuroticisme'; een indicatie van psychisch en lichamelijk disfunctioneren. De SCL-90 bestaat uit 90 items die beantwoord dienen te worden door gebruik te maken van een 5-punts Likert-schaal. Een hoge score op de subschalen indiceert het ervaren van veel psychische en/of lichamelijke klachten, en een lage score op de schalen indiceert het ervaren van weinig psychische en/of lichamelijke klachten.

\section{Neuropsychologische testen}

De neuropsychologische testbatterij bestond uit de Delayed-Match-to-Samplesubtest uit de Cambridge Neuropsychologische Automatische Testbatterij (CANTAB), de Verbal fluencytest, de Concept Shifting Test, de 15Woorden Test en ten slotte de SymboolSubstitutie-Coderen-subtest uit de Wechsler Adult Intelligence Scale (WAIS). Hieronder zullen de testen uit de testbatterij afzonderlijk toegelicht worden.

De Delayed-Match-to-Sample-test is een subtest uit de Cambridge Neuropsychologische Automatische Testbatterij (CANTAB; http://www.cambridgecognition.com/canta b/cognitive-tests/memory/delayedmatching-to-sample-dms). Het simultane visuele 'matching'-onderdeel van deze test dat in het huidige onderzoek gebruikt werd, meet het vermogen van simultane visuele 'matching' van nongeverbaliseerde patronen. Dit is een taak waarbij ruimtelijk inzicht vereist is.

De Verbal fluency-test meet 'verbale vloeiendheid'. De proefpersoon moet binnen de gestelde tijd zoveel mogelijk woorden opnoemen die beginnen met een bepaalde letter. Dit wordt driemaal herhaald met drie verschillende letters. De totaalscore is opgebouwd uit het totaal aantal bedachte woorden met de drie letters $[43,44]$.

De Concept Shifting Test meet shifting/cognitieve flexibiliteit. Shifting/cognitieve flexibiliteit valt onder 
de cognitieve functie 'executief functioneren'. Bij de geselecteerde test krijgen de deelnemers een blad met daarop kleine cirkels met daarin een letter of een cijfer. Het is de bedoeling dat de proefpersonen zo snel mogelijk de cijfers één tot en met acht en de letters A tot en met $\mathrm{H}$ afwisselend met elkaar verbinden in de juiste oplopende volgorde (1-A-2-B, ... 8-H). De tijd die de proefpersoon nodig heeft om deze taak te voltooien wordt, met nog enkele correcties die meeberekend worden, gezien als de Concept Shifting Test-score. Een lagere tijdsscore staat gelijk aan een betere prestatie. Met het aantal goede (en foute) verbindingen kan eventueel rekening worden gehouden tijdens de interpretatie van testscores [45].

De 15-Woorden Test meet het (episodische) verbale korte- en langetermijngeheugen. Tijdens de testafname wordt een reeks van 15 woorden, 5 maal verbaal aangeboden. $\mathrm{Na}$ elke afname wordt gevraagd om zoveel mogelijk woorden te reproduceren (i.e. kortetermijngeheugen). Vervolgens wordt de uitgestelde reproductie getest door na 10 minuten te vragen welke woorden van de oorspronkelijke woordenlijst nog herinnerd kunnen worden (i.e. langetermijngeheugen). Tot slot wordt uit een lijst met 30 woorden nagegaan welke woorden nog herkend worden (i.e. herkenningsvermogen). De score wordt gegenereerd uit het totaal aantal goede items [43, 46-48].

\section{De Symbool-Substitutie-Coderen-test is} een subtest uit de Wechsler Adult Intelligence Scale (WAIS) en meet verwerkingssnelheid. De deelnemer dient aan de hand van een testsleutel (elk cijfer onder de 10 staat gelijk aan een symbool) de gegeven getallen op een opgaveblad te voorzien van de bijbehorende symbolen. De proefpersoon poogt binnen de gestelde tijd zo ver mogelijk te komen. Een correct gegenereerd symbool bij een cijfer levert één punt op en het aantal behaalde punten binnen de gestelde tijd staat gelijk aan de totaalscore $[49,50]$.

\section{Procedure}

Op twee testmomenten heeft een meting plaatsgevonden. Inhoudelijk was de invulling van deze testmomenten (de testbatterij) zowel voor de transmannen als voor de twee controlegroepen identiek. De transmannen ontvingen echter, in tegenstelling tot de controlegroepen, zowel voorafgaand aan de eerste meting als tussen de twee meetmomenten een hormoonbehandeling. De controlegroepen ontvingen tijdens de gehele testperiode geen interventie.

Om bij de transmannen een baseline te creëren waarbij de activerende effecten van geslachtshormonen geminimaliseerd werden tijdens het onderzoek, werd een GnRH-analoog gegeven om de gonadale productie van geslachtshormonen bij de transmannen te onderdrukken. Deze gonadale onderdrukking startte 8 weken voorafgaand aan de eerste testmeting. De controlegroepen ontvingen geen behandeling voorafgaand aan de eerste meting. Op het eerste meetmoment werd de testbatterij afgenomen bij alle drie de onderzoeksgroepen.

$\mathrm{Na}$ de voorbehandeling van 8 weken met een $\mathrm{GnRH}-$ analoog bij de transmannen, werd de hormoontherapie na het eerste meetmoment aangepast bij deze groep. De transmannen ontvingen vanaf dat moment, naast een GnRH-analoog, tevens testosteron en een aromataseremmer. De controlegroepen ontvingen geen behandeling tussen het eerste en tweede meetmoment. De tweede meting vond 16 weken na de eerste meting plaats. Op dit tweede meetmoment werd de testbatterij opnieuw afgenomen bij alle drie de 
onderzoeksgroepen. In Figuur 1 is de procedure per onderzoeksgroep weergegeven.

\section{Transmannen}

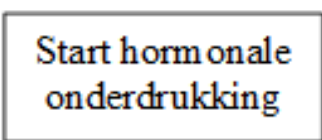

8 weken

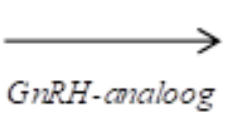

16 weken

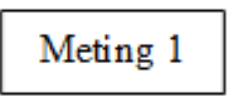

Meting 2
GnRH-analoog

Testosteron

Aromataseremmer

Vrouwen (controlegroep)

16 weken

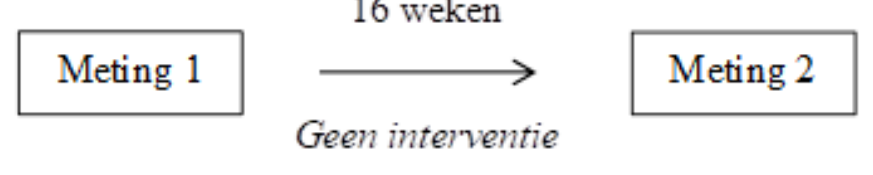

\section{Mannen (controlegroep)}

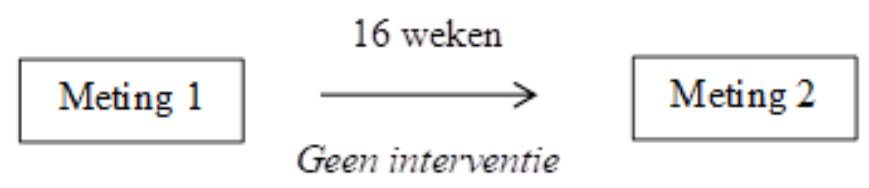

Figuur 1. Schematisch overzicht van de testperiode van de transmannen en de twee controlegroepen.

\section{Statistische analyse}

Hormoon waarden, vragenlijstscores en neuropsychologische testscores werden geanalyseerd door middel van mixed ANOVA. De tussen-subject variabele was Groep met drie niveaus (transmannen, vrouwen, mannen) en de herhaalde metingen factor had twee niveaus (meting 1 en 2). Significante effecten werden nader getoetst met onafhankelijke t-toetsen. Als significantie werd $p \leq .05$ gehanteerd.

\section{Resultaten}

Preliminaire analyses

In Figuur 2, 3, 4 en 5 zijn de concentratie van testosteron, estradiol, het luteïniserend hormoon en het follikelstimulerend hormoon weergegeven. Belangrijk is de significante stijging van het testosteronlevel in het bloed bij het tweede meetmoment ten opzichte van het eerste meetmoment bij de transmannen (interactie-effect Groep (transmannen, vrouw, man) x Meting (1 versus 2): $F$ (2, $54)=58.40, p<.01)$; het effect van de hormoonbehandeling bij de transmannen met testosteron is hier duidelijk zichtbaar (zie Figuur 2). Uit Figuur 3 en 4 is op te maken dat het estradiol-level (interactieeffect Groep x Meting: $F(2,54)=1.02, p$ $=.35$ ) en het luteïniserend hormoonlevel 
(interactie-effect Groep x Meting : $F$ (2, $54)=0.70, p=.50)$ grotendeels constant bleven. Een significante toename van het follikelstimulerend hormoonlevel werd geconstateerd (interactie-effect Groep x Meting: $F(2,54)=9.07, p<.01)$, zie Figuur 5.

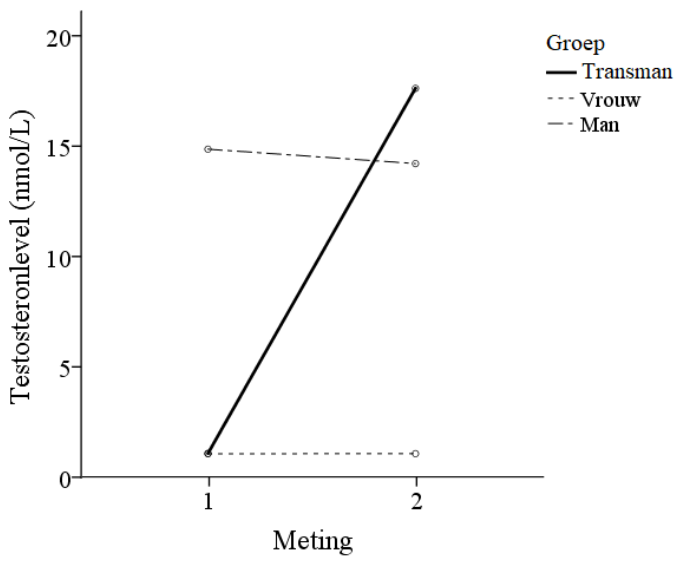

Figuur 2. Testosteronconcentratie (nmol/L) van de deelnemers $(n=57)$ op de twee meetmomenten.

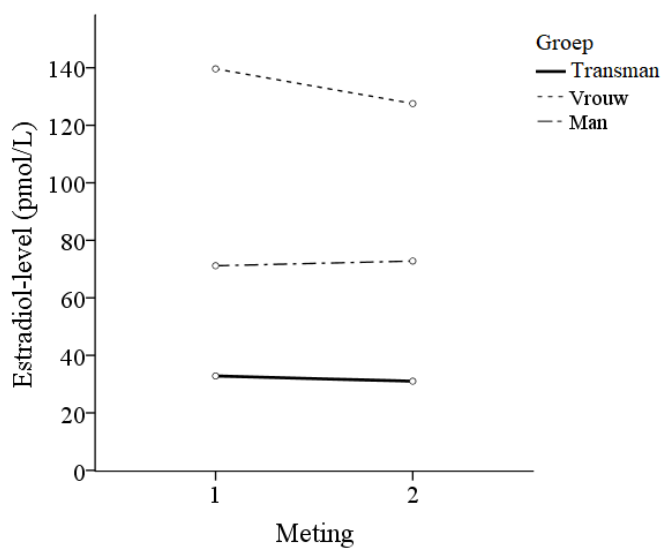

Figuur 3. Estradiolconcentratie (pmol/L) van de deelnemers $(n=57)$ op de twee meetmomenten.

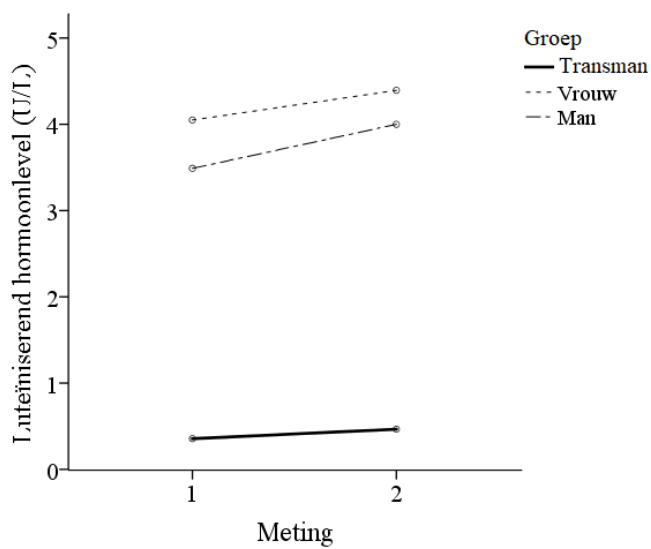

Figuur 4. Luteïniserend hormoonconcentratie (U/L) van de deelnemers $(n=57)$ op de twee meetmomenten.

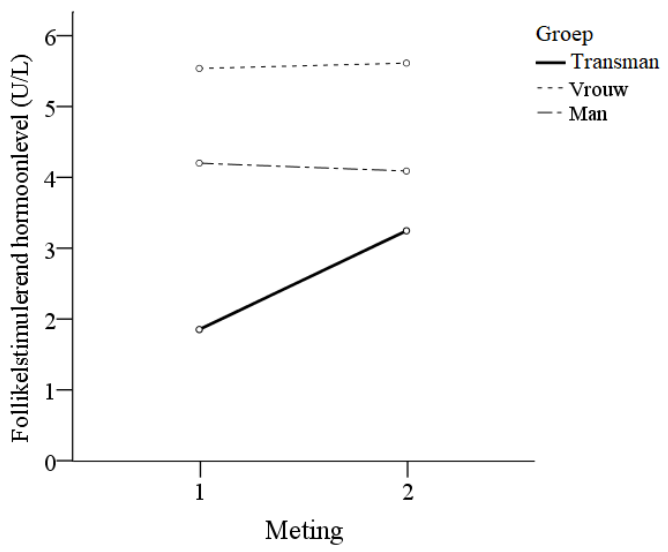

Figuur 5. Follikelstimulerend hormoonconcentratie (U/L) van de deelnemers $(n=57)$ op de twee meetmomenten.

De estradiol- en luteïniserend hormoonconcentraties van de transmannen verschilde significant ten opzichte van de controlegroepen (respectievelijk: $F(2,54)$ $=78.52, p=.74 ; F(2,54)=69.23, p<.01$; $F(2,54)=17.53, p<.01)$. Het gemiddelde estradiol-niveau lag bij de transmannen (M $=31.11, \mathrm{SE}=5.27)$ lager dan bij de vrouwen $(\mathrm{M}=133.59, \mathrm{SE}=6.18 ; t(17.47)$ $=-9.86, p<.01)$ en de mannen $(\mathrm{M}=71.97$, $\mathrm{SE}=5.67 ; \mathrm{t}(39)=-8.25, p<.01)$. De 
gemiddelde luteïniserend

hormoonconcentratie lag bij de transmannen $(\mathrm{M}=0.41, \mathrm{SE}=0.24)$ lager dan bij de vrouwen $(\mathrm{M}=4.22, \mathrm{SE}=0.28$; $t(16.55)=-8.70, p<.01)$ en de mannen $(\mathrm{M}$ $=3.75, \mathrm{SE}=0.26 ; t(23.97)=-13.06, p<$ $.01)$.
Hoofdanalyses

Een overzicht van de vragenlijstresultaten (i.e. emotioneel welzijn) en neuropsychologische testresultaten (i.e. cognitieve functioneren) zijn in Tabel 3 weergegeven. Alle scores werden geanalyseerd door middel van mixed ANOVA. Significante effecten werden nader onderzocht met onafhankelijke ttoetsen.

Tabel 3

Overzicht van de afgenomen (sub)testen en p-waarden

\begin{tabular}{llll} 
Test en subschalen & $\begin{array}{l}\text { Interactie } \\
\text { effect }(\boldsymbol{p} \text { - } \\
\text { waarde) }\end{array}$ & $\begin{array}{l}\text { Hoofdeffect } \\
\text { Sekse }(\boldsymbol{p} \text { - } \\
\text { waarde) }\end{array}$ & $\begin{array}{l}\text { Hoofdeffect } \\
\text { Meting }(\boldsymbol{p} \text { - } \\
\text { waarde) }\end{array}$ \\
\hline $\begin{array}{l}\text { Hospital Anxiety and Depression Scale (HADS) } \\
\text { Depressie-subschaal }\end{array}$ & .40 & .33 & .99 \\
Angst-subschaal & .63 & .62 & .41 \\
Symptom Checklist (SCL-90) & & & \\
Angst-subschaal & .21 & .30 & .11 \\
Agorafobie-subschaal & .14 & .16 & .39 \\
Depressie-subschaal & .32 & .48 & .34 \\
Somatische klachten-subschaal & .98 & .065 & .64 \\
Insufficiëntie van denken en handelen-subschaal & .50 & .30 & .34 \\
Wantrouwen en interpersoonlijke sensitiviteit-subschaal & .35 & .93 & .36 \\
Hostiliteit-subschaal & .61 & $\mathbf{. 0 2 4}$ & $\mathbf{. 0 4 1}$ \\
Slaapproblemen-subschaal & .14 & $\mathbf{. 0 1 4}$ & .58 \\
Psychoneuroticisme-subschaal & .38 & .33 & $<.01$ \\
Cambridge Neuropsychologische Automatische & & & \\
Testbatterij (CANTAB) & & & \\
Delayed-Match-to-Sample-subschaal & .91 & .48 & .26 \\
Simultane visuele 'matching'-testonderdeel & & & \\
Verbal fluency-test & .22 & $\mathbf{. 0 3 7}$ & $<.01$ \\
Concept shifting task & .19 & .94 & .50 \\
15-Woorden Test & .81 & $\mathbf{. 0 0 6}$ & $\mathbf{. 0 3 4}$ \\
Wechsler Adult Intelligence Scale (WAIS) & & & \\
Symbool-Substitutie-subschaal & .32 & $<.01$ & $\mathbf{. 0 0 1}$ \\
& & &
\end{tabular}

Vragenlijsten

Met betrekking tot zowel de Depressieschaal als de Angst-schaal van de HADS bleek geen sprake te zijn van significante interactie-effecten tussen Groep en Meting $($ respectievelijk: $F(2,52)=0.93, p=.40$ 
en $F(2,53)=0.46, p=.63)$. Tevens bestond er met betrekking tot zowel de HADS-depressiescores als de HADSangstscores geen significant verschil tussen de transmannen, vrouwen en mannen (respectievelijk $F(2,52)=1.14, p=.33$ en $F(2,53)=0.49, p=.62)$. Daarnaast werden geen significante hoofdeffecten gevonden voor Meting met betrekking tot de subschalen Depressie en Angst: respectievelijk $F(1,52)=0.00, p=.99$ en $F(1,53)=0.69, p=.41$.

Bij geen van de subschalen van de SCL-90 werd een significant interactie-effect gevonden: Angst-schaal $(F(2,52)=1.59$, $p=.21)$, Agorafobie-schaal $(F(2,52)=$ $2.04, p=.14)$, Depressie-schaal $(F(2,51)$ $=1.16, p=.32)$, Somatische klachtenschaal $(F(2,53)=0.018, p=.98)$, Insufficiëntie van denken en handelenschaal $(F(2,52)=0.70, p=.50)$, Wantrouwen en interpersoonlijke sensitiviteit-schaal $(F(2,51)=1.07, p=$ $.35)$, Hostiliteit-schaal $(F(2,52)=0.50, p$ $=.61)$ en tot slot de Psychoneuroticismeschaal $(F(2,49)=0.99, p=.38)$. De behaalde scores op de Slaapproblemenschaal werden, gezien de schending van homogeniteit van varianties (meting $1: F$ $(2,53)=8.28, p=.001$, meting $2: F(2,53)$ $=5.65, p=.006$ ), getransformeerd door gebruik te maken van de wortelfunctie. Hierna was de homogeniteit van varianties niet langer geschonden. Uit een mixed ANOVA bleek dat bij de Slaapproblemenschaal geen sprake was van een significant interactie-effect tussen Groep en Meting ( $F$ $(2,53)=2.03, p=.14)$.

Bij twee subschalen werd een significant hoofdeffect voor Groep gevonden: de Hostiliteit-schaal $(F(2,52)=4.01, p=$ $.024)$ en de Slaapproblemen-schaal $(F(2$, $53)=4.61, p=.014)$; zie Figuur 6 en 7. De bijbehorende effectgrootte (respectievelijk $\eta 2=.13$ en $\eta 2=.15$ ) indiceert respectievelijk een gemiddeld effect en een groot effect (Cohen, 1988, in Pallant, 2007). De transmannen $(\mathrm{M}=0.50, \mathrm{SE}=$ 0.089 ) scoorden significant hoger op de Hostiliteit-schaal dan de vrouwen $(\mathrm{M}=$ $0.13, \mathrm{SE}=0.10 ; t(35)=2.44, p=.020)$, maar de transmannen verschilden niet significant van de mannen $(\mathrm{M}=0.24, \mathrm{SE}=$ $0.096 ; t(37)=1.73, p=.092)$ op de

Hostiliteit-schaal. Op de Slaapproblemenschaal scoorden de transmannen $(\mathrm{M}=$ $0.87, \mathrm{SE}=0.098)$ zowel significant hoger dan de vrouwen $(\mathrm{M}=0.44, \mathrm{SE}=0.12$; $t(36)=2.78, p=.009)$ als de mannen $(\mathrm{M}=$ $0.53, \mathrm{SE}=0.11 ; t(38)=2.21, p=.033)$. Voor de overige subschalen werd geen significant hoofdeffect voor Groep gevonden: de Angst-schaal $(F(2,52)=$ $1.22, p=.30)$, Agorafobie-schaal $(F(2,52)$ $=1.88, p=.16)$, Depressie-schaal $(F(2$, $51)=0.74, p=.48)$, Somatische klachtenschaal $(F(2,53)=2.88, p=.065)$, Insufficiëntie van denken en handelenschaal $(F(2,52)=1.24, p=.30)$, Wantrouwen en interpersoonlijke sensitiviteit-schaal $(\mathrm{F}(2,51)=0.075, \mathrm{p}=$ .93) en tot slot de Psychoneuroticismeschaal $(\mathrm{F}(2,49)=1.15, \mathrm{p}=.33)$.

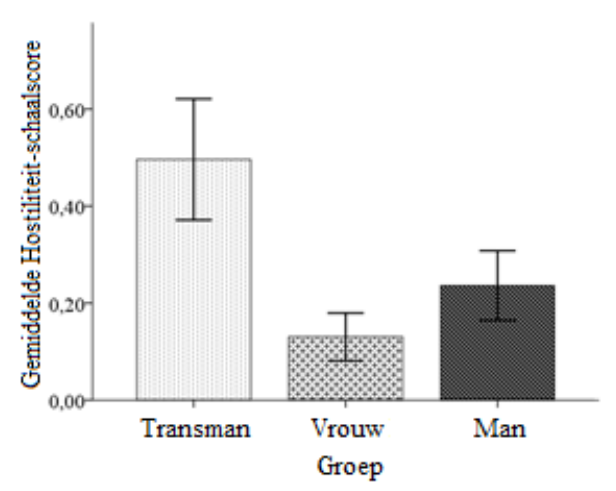

Figuur 6. Gemiddelde scores $( \pm \mathrm{SE})$ van de transmannen $(\mathrm{n}=21)$, de vrouwen $(\mathrm{n}=16)$ en de mannen $(\mathrm{n}=18)$ op de Hostiliteitschaal van de SCL-90. 


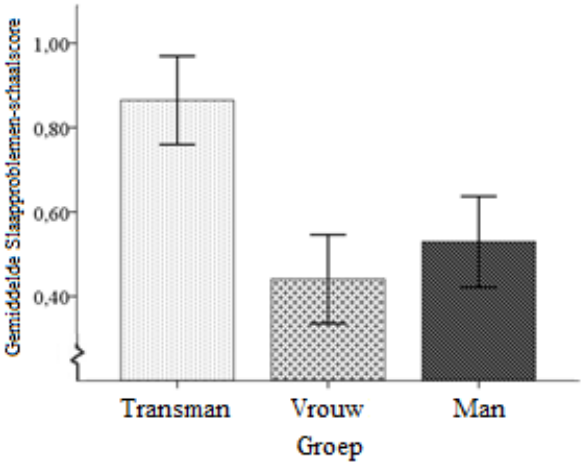

Figuur 7. Gemiddelde scores $( \pm \mathrm{SE})$ van de transmannen $(\mathrm{n}=22)$, de vrouwen $(\mathrm{n}=16)$ en de mannen $(\mathrm{n}=18)$ op de op de Slaapproblemen-schaal van de SCL-90.

Tot slot werd bij twee subschalen van de SCL-90 een significant hoofdeffect voor Meting gevonden: de Hostiliteit-schaal $(F$ $(1,52)=4.38, p=.041)$ en de Psychoneuroticisme-schaal $(F(1,49)=$ $23.39, p<.01)$, zie Figuur 8. De bijbehorende effectgrootte (respectievelijk $\eta 2=.078$ en $\eta 2=.32$ ) indiceert respectievelijk een gemiddeld effect en een groot effect (Cohen, 1988, in Pallant, 2007). De scores die door de proefpersonen behaald werden op de Hostiliteit-schaal tijdens het tweede meetmoment $(\mathrm{M}=0.35, \mathrm{SE}=0.074)$ waren significant hoger dan die van het eerste meetmoment $(\mathrm{M}=0.22, \mathrm{SE}=$ 0.052). Dit is tevens het geval bij de Psychoneuroticisme-schaal; de door de proefpersonen behaalde scores tijdens het tweede meetmoment $(\mathrm{M}=0.59, \mathrm{SE}=$ 0.083 ) waren significant hoger dan die van het eerste meetmoment $(\mathrm{M}=0.26, \mathrm{SE}=$ 0.026). Voor de overige subschalen zijn geen significante hoofdeffecten gevonden voor Meting: Angst-schaal $(F(1,52)=$ $2.61, p=.11)$, Agorafobie-schaal $(F(1,52)$ $=0.75, p=.39)$, Depressie-schaal $(F(1$, $51)=0.92, p=.34)$, Somatische klachtenschaal $(F(1,53)=0.22, p=.64)$, Insufficiëntie van denken en handelenschaal $(F(1,52)=0.94, p=.34)$, Wantrouwen en interpersoonlijke sensitiviteit-schaal $(F(1,51)=0.87, p=$ .36) en de Slaapproblemen-schaal $(F(1$, $53)=0,32, p=.58)$.

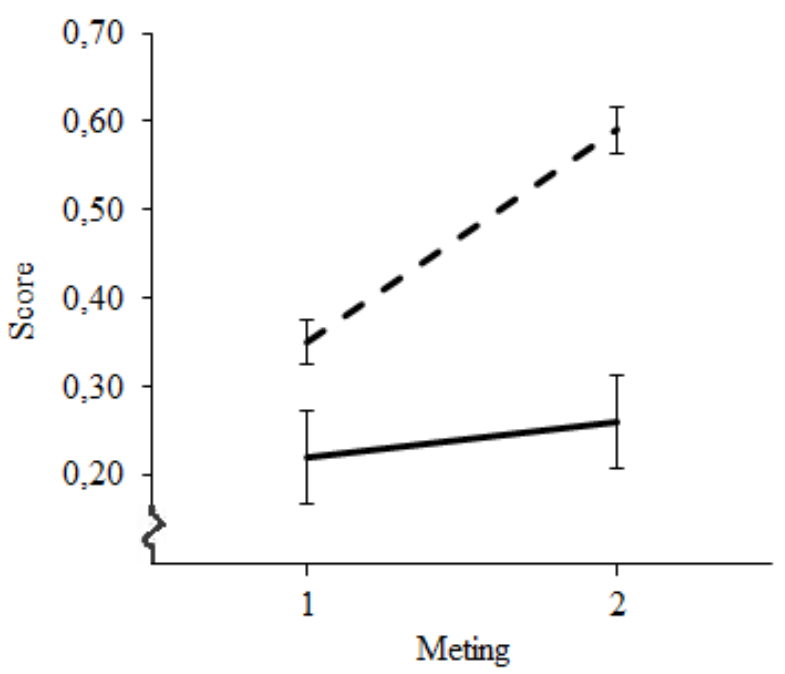

Gemiddelde Hostiliteit-schaal score

- - Gemiddelde Psychoneuroticisme-schaalscore

Figuur 8. Gemiddelde scores $( \pm \mathrm{SE})$ op de twee meetmomenten op de Hostiliteit-schaal $(\mathrm{n}=$ $55)$ en de Psychoneuroticisme-schaal $(\mathrm{n}=52)$ van de SCL-90. 
Neuropsychologische testbatterij

De Delayed-Match-to-Sample-subtestscore werd gebaseerd op de behaalde simultane visuele 'matching'-score. De simultane visuele 'matching'-scores indiceerden geen interactie-effect tussen Groep en Meting $(F$ $(2,53)=0.10, p=.91)$, geen hoofdeffect voor Groep $(F(2,53)=0.75, p=.48)$ en geen hoofdeffect voor Meting $(F(1,53)=$ $1.31, p=.26$ ).

Met betrekking tot de Verbal fluencytestscores was er sprake van een hoofdeffect voor Groep $(F(2,54)=3.52, p$ $=.037)$; zie Figuur 9. De bijbehorende effectgrootte $(\eta 2=.37)$ indiceert een groot effect (Cohen, 1988, in Pallant, 2007). De transmannen $(\mathrm{M}=35.66, \mathrm{SE}=2.05)$ scoorden zowel significant lager dan de vrouwen $(\mathrm{M}=42.31, \mathrm{SE}=2.40 ; t(36)=$ $2.14, p=.039)$ als de mannen $(\mathrm{M}=42.82$, $\mathrm{SE}=2.21 ; t(39)=-2.40, p=.021)$ op de Verbal fluency-test. Daarnaast was tevens sprake van een hoofdeffect voor Meting $(F$ $(1,54)=31.30, p<.01)$; zie Figuur 10. De bijbehorende effectgrootte $(\eta 2=.12)$ indiceert een gemiddeld effect [51].

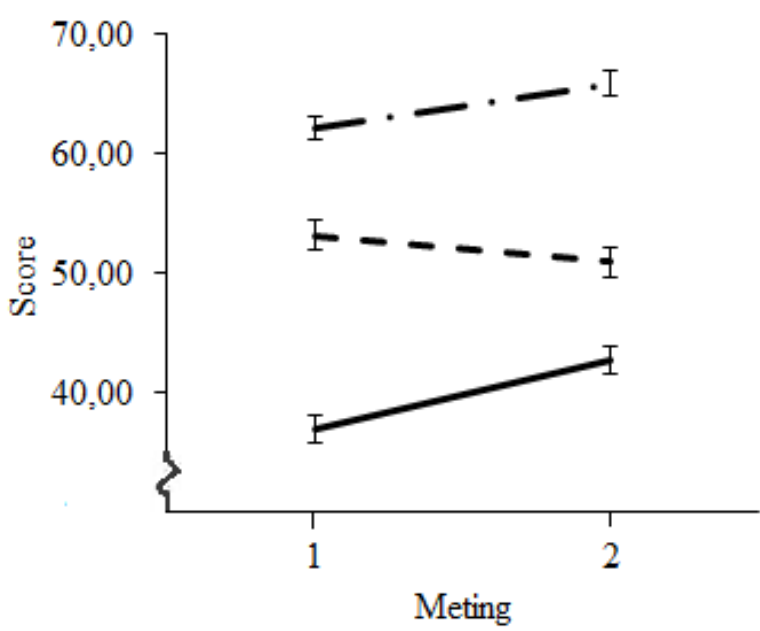

De Verbal fluency-testscores op het eerste meetmoment $(\mathrm{M}=37.02, \mathrm{SE}=1.17)$ waren significant lager dan op het tweede meetmoment $(\mathrm{M}=42.81, \mathrm{SE}=1.57)$.

Aangezien dit voor het gemiddelde van de drie de groepen geldt kan dit op een leereffect wijzen.

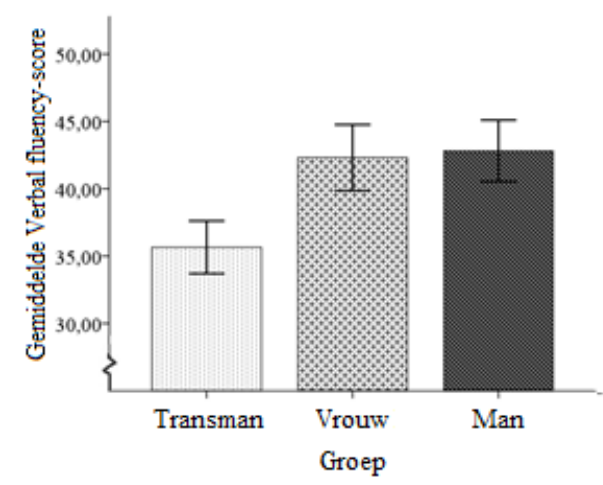

Figuur 9. Gemiddelde scores $( \pm \mathrm{SE})$ van de transmannen $(\mathrm{n}=22)$, de vrouwen $(\mathrm{n}=16)$ en de mannen $(\mathrm{n}=19)$ op de Verbal fluency-test.

Figuur 10. Gemiddelde scores $( \pm \mathrm{SE})$ op de twee meetmomenten op de Verbal fluency-test (n $=57$; geen vast scorebereik), de 15 -Woorden Test $(n=56$; maximum score $=75)$ en de Symbool-Substitutie-Coderen-subtests $(n=57$; maximum score $=90)$. 
Aangaande de Concept Shifting Testscores was geen sprake van een interactieeffect tussen Groep en Meting $(F(2,54)=$ $1.74, p=.19)$, geen hoofdeffect voor Groep $(F(2,54)=0.063, p=.94)$ en geen hoofdeffect voor Meting $(F(1,54)=0.47$, $p=.50)$.

Met betrekking tot de 15-Woorden Testresultaten bleek sprake te zijn van een hoofdeffect voor Groep $(F(2,53)=5.69, p$ $=.006)$; zie Figuur 11. De bijbehorende effectgrootte $(\eta 2=.18)$ indiceerde een groot effect (Cohen, 1988, in Pallant, 2007). De transmannen $(\mathrm{M}=46.86, \mathrm{SE}=$ 1.86) scoorden zowel significant lager dan de vrouwen $(\mathrm{M}=56.37, \mathrm{SE}=2.26 ; t(35)=$ $-2.97, \mathrm{p}=.005)$ als de mannen $(\mathrm{M}=52.95$, $\mathrm{SE}=2.00 ; t(39)=-2.46, p=.019)$ op de 15 -Woorden Test. Daarnaast was sprake van een hoofdeffect voor Meting $(F(1,53)$ $=4.74, p=.034)$; zie Figuur 10. De bijbehorende effectgrootte $(\mathrm{\eta} 2=.082)$ indiceert een gemiddeld effect (Cohen, 1988, in Pallant, 2007). De 15-Woorden Test-scores van het eerste meetmoment (M $=53.17, \mathrm{SE}=1.24)$ waren significant hoger dan van het tweede meetmoment $(\mathrm{M}$ $=50.95, \mathrm{SE}=1.33$ ).

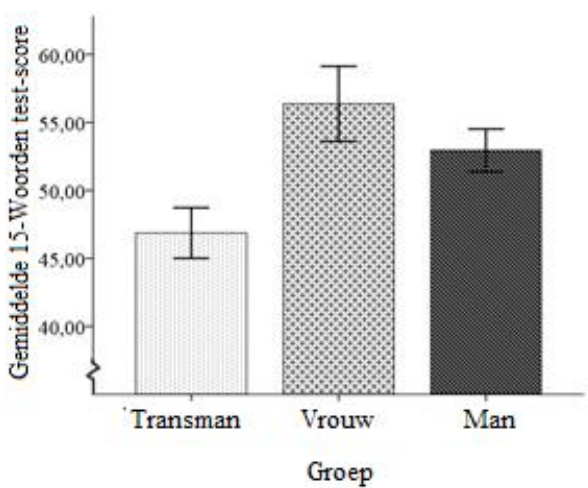

Figuur 11. Gemiddelde scores $( \pm \mathrm{SE})$ van de transmannen $(\mathrm{n}=22)$, de vrouwen $(\mathrm{n}=$ $15)$ en de mannen $(n=19)$ op de 15 Woorden Test.

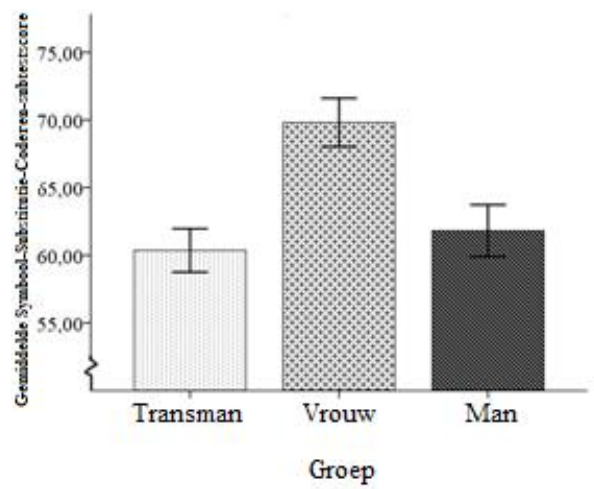

Figuur 12. Gemiddelde scores $( \pm \mathrm{SE})$ van de transmannen $(\mathrm{n}=22)$, de vrouwen $(\mathrm{n}=$ $16)$ en de mannen $(n=19)$ op de SymboolSubstitutie-Coderen-subtest van de WAIS.

De Symbool-Substitutie-Coderensubtestscores indiceerden een hoofdeffect voor Groep $(F(2,54)=35.01, p<.01)$; zie Figuur 12. De bijbehorende effectgrootte $(\mathrm{\eta} 2=.22)$ indiceert een groot effect [51]. De transmannen $(\mathrm{M}=60.36, \mathrm{SE}=1.65)$ scoorden significant lager dan de vrouwen $(\mathrm{M}=69.81, \mathrm{SE}=1.93 ; t(36)=-3.90, p<$ $.01)$, maar verschilden niet significant van de mannen $(\mathrm{M}=61.82, \mathrm{SE}=1.77 ; t(39)=$ $-0.59, p=.56)$ op de Symbool-SubstitutieCoderen-subtest. Daarnaast was tevens sprake van een hoofdeffect voor Meting ( $F$ $(2,54)=7.63, p=.001)$; zie Figuur 10. De bijbehorende effectgrootte $(\eta 2=.042)$ indiceert een klein effect [51]. De Symbool-Substitutie-Coderensubtestscores van het eerste meetmoment $(\mathrm{M}=62.12, \mathrm{SE}=1.03)$ waren significant lager dan van het tweede meetmoment $(\mathrm{M}$ $=65.87, \mathrm{SE}=1.13$ ).

\section{Discussie}

Overzicht

In de huidige studie werd nagegaan wat het effect van een hormoonbehandeling is op het emotioneel welzijn en het cognitief functioneren van transmannen. De verwachting was dat het emotioneel welzijn van de transmannen zou 
veranderen na het ondergaan van de hormoonbehandeling. Daarnaast was het vermoeden dat bij transmannen de 'mantypische' cognitieve vaardigheden (ruimtelijk inzicht) zouden versterken en de 'vrouw-typische' cognitieve vaardigheden (verbale vaardigheden) zouden verzwakken als gevolg van de ontvangen hormoontherapie. Verder werd verwacht dat de hormoontherapie bij transmannen geen invloed zou hebben op shifting of het verbale geheugen van de transmannen. Tot slot werd verwacht dat de verwerkingssnelheid van transmannen zou veranderen ten gevolge van de hormoontherapie.

De conclusie werd getrokken dat het emotioneel welzijn en het cognitief functioneren van transmannen ten opzichte van de controlegroepen niet beduidend leek te veranderen na een hormoontherapie van 16 weken. Hieruit werd afgeleid dat alle in het huidige onderzoek opgestelde hypotheses, uitgezonderd de hypotheses met betrekking tot 'shifting' en 'verbaal geheugen' waarbij de verwachting was dat er geen verandering zou optreden, werden verworpen. Hieronder worden de gevonden onderzoeksresultaten nader toegelicht.

\section{Emotioneel welzijn}

Een aanzienlijk deel van de transgenderpopulatie ervaart lijdensdruk omdat hun lichaam en genderidentiteit niet overeenkomen [1]. Deze lijdensdruk verklaart mogelijk waarom psychische problemen frequent voorkomen in deze groep [13]. Een hormoonbehandeling wordt daarom voor vele transgender personen gezien als een langverwachte wens om het lichaam beter overeen te laten komen met hun genderidentiteit, en heeft invloed op zowel het uiterlijk als de emotionele staat van transgender personen $[3,16,22]$. In het huidige onderzoek werden echter geen veranderingen in het emotioneel welzijn bij de transmannen geconstateerd. Deze resultaten lijken de onderzoeksresultaten van Van Goozen et al. [27] te bevestigen: zij concludeerden dat er geen stemmingsveranderingen bij transgender personen plaatsvinden na een behandelduur van 3 maanden. Opvallender is echter dat de huidige resultaten niet overeen komen met resultaten uit andere studies die juist verbeterd emotioneel welzijn en kwaliteit van leven constateren $[3,13,16,22-25]$.

Buiten de oorspronkelijke onderzoeksdoelen werd tevens gekeken naar eventuele andere noemenswaardige effecten. Hieruit blijkt dat transmannen met betrekking tot emotioneel welzijn gemiddeld aanzienlijk meer hostiliteit en slaapproblemen ervoeren dan de referentiegroepen van vrouwen en mannen. De geobserveerde hogere scores op slaapen hostiliteit-schalen onder transmannen geven aanleiding hierop alert te zijn bij deze groep. Als wij echter in aanmerking nemen dat deze scores nog steeds relatief laag zijn, geven de huidige resultaten geen aanleiding om hier problematiek in te zien. Echter, het is goed om bedacht te zijn dat er bij individuele personen wel sprake kan zijn van problematische slaap of hostiliteit. In dat geval kan gedacht worden aan het inzetten van oplossingsgerichte methoden en copingstrategieën, en eventuele aanvullende medicatie voor bestaande slaapproblematiek.

Ruimtelijk inzicht en verbale vaardigheden In het huidige onderzoek werd de versterking van de 'man-typische' cognitieve vaardigheid, ruimtelijke inzicht, bij de transmannen daarentegen niet geconstateerd, ondanks dat de bereikte testosteron concentratie hoger was dan die van de controlemannen.

Het in de literatuur beschreven verschil 
tussen mannen en vrouwen met betrekking tot verbale vaardigheden is minder eenduidig. Wel constateerden Weiss, Kemmler, Deisenhammer, Fleischhacker en Delazer [30] dat vrouwen beter presteren op verbale vloeiendheid. Aanvullend vonden Van Goozen, CohenKettenis, Gooren, Frijda en Van de Poll [27] specifiek voor transmannen dat de verbale vloeiendheid afneemt na het ondergaan van hormoontherapie. In tegenstelling tot de verwachting dat de hormoonbehandeling effect zou hebben op de verbale vloeiendheid van transmannen omdat verbale capaciteiten beschouwd worden als een 'vrouw-typische' vaardigheid, bleek dit in het huidige onderzoek niet het geval. Het bleek zelfs dat transmannen lager scoorden op verbale vloeiendheid dan vrouwen en mannen, ongeacht de testosteronbehandeling. Op basis van de bestaande literatuur en logisch redeneren zou verwacht worden dat de verbale capaciteiten van de transmannen tussen de waarden van vrouwen en mannen in zouden liggen, of eventueel meer naar de kant van de vrouwen of meer naar de kant van de mannen. De lagere prestatie van transmannen op verbale vloeiendheid is dus niet direct verklaarbaar vanuit de literatuur. De meest voor de hand liggende verklaring binnen dit huidige onderzoek is het lagere opleidingsniveau van de transmannen en houdt waarschijnlijk verband met het werven van de controlepersonen op de campus van de universiteit.

\section{Executief functioneren}

De cognitieve functies 'executief functioneren (shifting)', 'verbaal geheugen' en 'verwerkingssnelheid' worden gezien als minder seksespecifieke cognities. Op het gebied van shifting is weinig onderzoek gedaan onder transgender personen en daarnaast wordt in bestaande studies geen aanleiding gegeven voor sekseverschillen. Uit de huidige onderzoeksresultaten bleek dat de hormoontherapie bij transmannen geen invloed heeft op shifting. De cognitieve functie 'shifting' lijkt niet beïnvloedbaar door testosteron bij transmannen.

Daarnaast werd geen groepsverschil gevonden tussen de shifting-prestaties van mannen, vrouwen en transmannen. Dit ondersteunt de bestaande literatuur waarin tot op heden eveneens geen sekseverschil is gevonden met betrekking tot deze executieve functie.

\section{Verbaal geheugen}

De verwachting dat het verbale geheugen van de transmannen onveranderd zou blijven door de hormoonbehandeling kwam tot stand op basis van onderzoeksresultaten van Kimura [39] en Gómez-Gil et al. [38]. Kimura constateerde dat vrouwen excelleren op het gebied van verbaal geheugen in vergelijking met mannen. De resultaten van Gómez-Gil et al. suggereerden echter dat testosteron geen invloed heeft op de verbale geheugenprestatie. In het huidige onderzoek werd verwacht dat niet testosteron, maar een andere component verantwoordelijk is voor het betere verbale geheugen onder vrouwen ten opzichte van mannen. Op basis van deze gegevens werd voorspeld dat de verbale geheugenprestatie van transmannen van voor de testosteronbehandeling niet zou veranderen ten opzichte van de verbale geheugenprestatie na 16 weken hormoontherapie. Zoals verwacht had de testosterontoediening inderdaad geen invloed op het verbale geheugen van de transmannen.

Wanneer wordt gekeken naar het algehele prestatieniveau van de participanten, werden wel verschillen gevonden tussen de onderzoeksgroepen. Op de verbale 
geheugentaak behaalden de transmannen gemiddeld een lagere score dan zowel de vrouwen als de mannen. Dit is een opvallend resultaat. In eerste instantie zou, net zoals bij de verbale vloeiendheid, eerder een bepaalde rangorde in de scores van transmannen, de vrouwenscores en mannenscores verwacht worden. Deze rangorde is echter niet meer vanzelfsprekend wanneer rekening wordt gehouden met de mogelijkheid dat een andere component, in plaats van testosteron, bepalend is bij de totstandkoming van de verbale geheugenscores. De lagere verbale geheugenscores hangen mogelijk samen met het lagere opleidingsniveau van de transmannen in deze studie in vergelijking met de controlepersonen (die geworven werden op de campus van de universiteit).

\section{Verwerkingssnelheid}

Volgens Camarata en Woodcock [40] presteren vrouwen beter dan mannen met betrekking tot verwerkingssnelheid. Roivainen [41] nuanceerde deze conclusie met haar stelling dat er wisselende resultaten gevonden zijn op het gebied van verwerkingssnelheid. Zij vond zelfs tevens situaties waarin mannen excelleren. In het huidige onderzoek kwam naar voren dat de verwerkingssnelheid van transmannen constant bleef tijdens de hormoontherapie. De verwerkingssnelheid-scores van de transmannen verschilden van de scores van de vrouwen wanneer de hormoontherapie buiten beschouwing werd gelaten: de transmannen hadden gemiddeld een lagere verwerkingssnelheid. Maar de transmannen verschilden niet van de mannen. In dit onderzoek verschillen de transmannen hierin dus van degenen met wie zij hun toegewezen geslacht delen bij geboorte (vrouwen), en zijn zij op dit gebied vergelijkbaar met personen met wie zij hun genderidentiteit delen (mannen). Rekening houdend met dezelfde overwegingen die hierboven genoemd zijn met betrekking tot de cognitieve domeinen 'verbale vloeiendheid' en 'verbaal geheugen', werd een verandering in scorepatroon verwacht als gevolg van de hormoonbehandeling. Aangezien in het huidige onderzoek de transmannen een lager opleidingsniveau hadden dan de controlegroepen, zal in vervolgonderzoek gezorgd moeten worden dat deze groepen wat betreft opleiding (en andere kenmerken) vergelijkbaar zijn om meer duidelijkheid te verschaffen over de scores op verbale vloeiendheid-, verbaal geheugen- en verwerkingssnelheid-taken van de transmannen ten opzichte van de mannen en/of vrouwen.

\section{Conclusie en aanbevelingen}

Het doel van het huidige onderzoek was het nagaan van de invloed van testosteron op het emotioneel welzijn en het cognitief functioneren van transmannen. De transmannen leken niet emotioneel te veranderen en geen 'vrouw-typisch' cognitiepatroon te ontwikkelen ten gevolge van de toegediende testosteron. Deze conclusie spreekt onderzoeksresultaten uit eerdere studies tegen. Desalniettemin werd het volgende resultaat gevonden in de huidige studie: transmannen hadden gemiddeld hogere scores op de slaap- en hostiliteitsschaal van de SCL-90 dan vrouwen en mannen. De scores waren niet dusdanig hoog om te kunnen spreken van problematiek, echter is het goed om bewust te zijn van de eventuele aanwezigheid van deze klachten bij transmannen. Aanvullend onderzoek naar slaap- en

hostiliteitssymptomen bij transmannen die hormoonbehandeling krijgen is derhalve wenselijk.

Een verklaring voor de discrepantie tussen de huidige resultaten en resultaten uit de reeds bestaande literatuur is dat eventuele verschillen die in de (transgender)populatie 
voorkomen, niet gedetecteerd zijn binnen deze studie omdat de steekproef klein was. Resultaten met betrekking tot het huidige onderzoek moeten derhalve met voorzichtigheid geïnterpreteerd worden. Gezien het geringe aantal transmannen in de populatie die daarbij ook hormoontherapie wil ondergaan, het voldoen aan inclusiecriteria en vanwege de hoge kosten van de MRI-scans en bereidheid om aan de studie deel te nemen, was het problematisch een grote onderzoeksgroep en dus tevens een hoge power te creëren. Het is daarnaast essentieel te beseffen dat het emotioneel welzijn niet enkel een product is van hormoontherapie, maar ook samenhangt met andere factoren zoals sociale steun. Ook wordt cognitief functioneren beïnvloedt door emotioneel welbevinden. Ook hiermee zal in vervolgonderzoek rekening mee gehouden moeten worden. Tot slot kan het zijn dat de 16 weken toedieningsperiode van testosteron niet lang genoeg is om daadwerkelijke effecten vast te stellen. Wellicht is een langere behandelperiode noodzakelijk voor het ontstaan van veranderingen. Gedegen onderzoek is belangrijk om het zorgproces en de kwaliteit van leven van transgender personen te kunnen verbeteren.

\section{Dankbetuiging}

Wij danken Dr. B.P.C. (Baudewijntje) Kreukels, Afdeling Medische Psychologie van Amsterdam UMC voor de degelijke en kritische becommentariëring van een eerdere versie van het manuscript.

\section{Referenties}

1. Grossman, A.H. and A.R. D'Augelli, Transgender youth and life-threatening behaviors. Suicide and life-threatening behavior, 2007. 37(5): p. 527-537.

2. Kuyper, L. and C. Wijsen, Gender identities and gender dysphoria in the Netherlands. Archives of sexual behavior, 2014. 43(2): p. 377-385.

3. Bishop, B.M., Pharmacotherapy considerations in the management of transgender patients: a brief review. Pharmacotherapy: The Journal of Human Pharmacology and Drug Therapy, 2015. 35(12): p. 1130-1139.

4. Goodrum, A.J., Gender identity 101: A transgender primer. Retrieved November, 1998. 16.

5. Clements-Nolle, K., R. Marx, R. Guzman and M. Katz, HIV prevalence, risk behaviors, health care use, and mental health status of transgender persons: implications for public health intervention. American journal of public health, 2001. 91(6): p. 915.

6. White, J.C. and M. Towensend, Transgender medicine: Issues and definitions. Journal of the Gay and Lesbian Medical Association, 1998. 2: p. 1-4.

7. Currah, P. and S. Minter, Unprincipled exclusions: The struggle to achieve judicial and legislative equality for transgender people. Wm. \& Mary J. Women \& L., 2000. 7: p. 37.

8. Smorenburg, T., Transgender. Kwetsbaar door anders zijn. Een kritische discoursanalyse van vier weblogs van transgenders in transitie van man naar vrouw in Nederland, een zorgethische reflectie op goede zorg en burgerschap. 2015, [s1]: sn.

9. Geerdinck, M., L. Muller, C. Verkleij, C. van Weert and C.B. voor de Statistiek, Transseksuelen in Nederland. Is er sprake van ongelijkheid, 2011.

10. Kuyper, L., Transgenders in Nederland: prevalentie en attitudes. Tijdschrift voor Seksuologie, 2012. 
36(2): p. 129-135.

11. Eklund, P., L. Gooren and P. Bezemer, Prevalence of transsexualism in the Netherlands. The British Journal of Psychiatry, 1988. 152(5): p. 638-640.

12. Wiepjes, C.M., N.M. Nota, C.J. de Blok, M. Klaver, A.L. de Vries, S.A. Wensing-Kruger, R.T. de Jongh, M.-B. Bouman, T.D. Steensma and P. Cohen-Kettenis, The Amsterdam cohort of gender dysphoria study (1972-2015): trends in prevalence, treatment, and regrets. The journal of sexual medicine, 2018. 15(4): p. 582-590.

13. Schlatterer, K., A. Yassouridis, K. Von Werder, D. Poland, J. Kemper and G.K. Stalla, A follow-up study for estimating the effectiveness of a cross-gender hormone substitution therapy on transsexual patients. Archives of sexual behavior, 1998. 27(5): p. 475-492.

14. Safer, J.D. and V. Tangpricha, Out of the shadows: it is time to mainstream treatment for transgender patients. Endocrine practice: official journal of the American College of Endocrinology and the American Association of Clinical Endocrinologists, 2008. 14(2): p. 248.

15. Kenagy, G.P., Transgender health: Findings from two needs assessment studies in Philadelphia. Health \& social work, 2005. 30(1): p. 19-26.

16. Davis, S.A. and S. Colton Meier, Effects of testosterone treatment and chest reconstruction surgery on mental health and sexuality in female-to-male transgender people. International Journal of Sexual Health, 2014. 26(2): p. 113-128.

17. Gooren, L.J., E.J. Giltay and M.C.
Bunck, Long-term treatment of transsexuals with cross-sex hormones: extensive personal experience. The Journal of Clinical Endocrinology \& Metabolism, 2008. 93(1): p. 19-25.

18. Zimman, L., Voices in transition: Testosterone, transmasculinity, and the gendered voice among femaleto-male transgender people. 2012, University of Colorado at Boulder.

19. Soleman, R.S., A. Staphorsius, P.T. Cohen-Kettenis, C.B. Lambalk, D.J. Veltman, M. Van Trotsenburg, P.G. Hompes, M. Drent, W. De Ronde and B.P. Kreukels, Oestrogens are not related to emotional processing: a study of regional brain activity in female-tomale transsexuals under gonadal suppression. Cerebral Cortex, 2016. 26(2): p. 510-516.

20. Giltay, E.J., L.J. Gooren, A.W. Toorians, M.B. Katan and P.L. Zock, Docosahexaenoic acid concentrations are higher in women than in men because of estrogenic effects. The American journal of clinical nutrition, 2004. 80(5): p. 1167-1174.

21. Kimura, D., Sex and cognition. Cambridge, MA: A Bradford Book. 2000, The MIT Press.

22. Newfield, E., S. Hart, S. Dibble and L. Kohler, Female-to-male transgender quality of life. Quality of Life Research, 2006. 15(9): p. 1447-1457.

23. Cohen-Kettenis, P.T. and S.H. Van Goozen, Sex reassignment of adolescent transsexuals: a followup study. Journal of the American Academy of Child \& Adolescent Psychiatry, 1997. 36(2): p. 263271.

24. Gómez-Gil, E., L. ZubiaurreElorza, I. Esteva, A. Guillamon, T. 
Godás, M.C. Almaraz, I. Halperin and M. Salamero, Hormone-treated transsexuals report less social distress, anxiety and depression. Psychoneuroendocrinology, 2012. 37(5): p. 662-670.

25. Gorin-Lazard, A., K. Baumstarck, L. Boyer, A. Maquigneau, S. Gebleux, J.C. Penochet, D. Pringuey, F. Albarel, I. Morange and A. Loundou, Is hormonal therapy associated with better quality of life in transsexuals? A cross-sectional study. The journal of sexual medicine, 2012. 9(2): p. 531-541.

26. Murad, M.H., M.B. Elamin, M.Z. Garcia, R.J. Mullan, A. Murad, P.J. Erwin and V.M. Montori, Hormonal therapy and sex reassignment: A systematic review and meta-analysis of quality of life and psychosocial outcomes. Clinical endocrinology, 2010. 72(2): p. 214-231.

27. Van Goozen, S.H., P.T. CohenKettenis, L.J. Gooren, N.H. Frijda and N.E. Van De Poll, Gender differences in behaviour: Activating effects of cross-sex hormones. Psychoneuroendocrinology, 1995. 20(4): p. 343-363.

28. Hausmann, M., D. Schoofs, H.E. Rosenthal and K. Jordan, Interactive effects of sex hormones and gender stereotypes on cognitive sex differences-A psychobiosocial approach.

Psychoneuroendocrinology, 2009. 34(3): p. 389-401.

29. Saccuzzo, D.P., A.S. Craig, N.E. Johnson and G.E. Larson, Gender differences in dynamic spatial abilities. Personality and Individual Differences, 1996. 21(4): p. 599607.

30. Weiss, E.M., G. Kemmler, E.A.
Deisenhammer, W.W.

Fleischhacker and M. Delazer, Sex differences in cognitive functions. Personality and individual differences, 2003. 35(4): p. 863875.

31. Gur, R.C., D. Alsop, D. Glahn, R. Petty, C.L. Swanson, J.A. Maldjian, B.I. Turetsky, J.A. Detre, J. Gee and R.E. Gur, An fMRI study of sex differences in regional activation to a verbal and a spatial task. Brain and language, 2000. 74(2): p. 157170.

32. Nyborg, H., Spatial ability in men and women: Review and new theory. Advances in Behaviour Research and Therapy, 1983. 5(2): p. 89-140.

33. Silverman, I., D. Kastuk, J. Choi and K. Phillips, Testosterone levels and spatial ability in men.

Psychoneuroendocrinology, 1999. 24(8): p. 813-822.

34. Slabbekoorn, D., S.H. Van Goozen, J. Megens, L.J. Gooren and P.T. Cohen-Kettenis, Activating effects of cross-sex hormones on cognitive functioning: a study of short-term and long-term hormone effects in transsexuals.

Psychoneuroendocrinology, 1999. 24(4): p. 423-447.

35. Wallentin, M., Putative sex differences in verbal abilities and language cortex: A critical review. Brain and language, 2009. 108(3): p. 175-183.

36. Welsh, M.C. and B.F. Pennington, Assessing frontal lobe functioning in children: Views from developmental psychology. Developmental neuropsychology, 1988. 4(3): p. 199-230.

37. Fisk, J.E. and C.A. Sharp, Agerelated impairment in executive functioning: Updating, inhibition, 
shifting, and access. Journal of clinical and experimental neuropsychology, 2004. 26(7): p. 874-890.

38. Gómez-Gil, E., S. Canizares, A. Torres, F. De La Torre, I. Halperin and M. Salamero, Androgen treatment effects on memory in female-to-male transsexuals. Psychoneuroendocrinology, 2009. 34(1): p. 110-117.

39. Kimura, D., Sex differences in the brain. Scientific american, 1992. 267(3): p. 118-125.

40. Camarata, S. and R. Woodcock, Sex differences in processing speed: Developmental effects in males and females. Intelligence, 2006. 34(3): p. 231-252.

41. Roivainen, E., Gender differences in processing speed: A review of recent research. Learning and Individual differences, 2011. 21(2): p. 145-149.

42. Van Hemert, B. and J. Ormel, Handleiding Hospital Anxiety and Depression Scale (HADS). 1996, Groningen.

43. Brand, N., in GGZ nieuws, M. Korpelshoek, Editor. 2021, ggz.nl.

44. Schmand, B., S. Groenink and M. Van den Dungen, Letterfluency: psychometrische eigenschappen en Nederlandse normen. Tijdschrift voor gerontologie en geriatrie, 2008. 39(2): p. 64-74.

45. Van der Elst, W., M.P. Van Boxtel, G.J. Van Breukelen and J. Jolles, The concept shifting test: adult normative data. Psychological assessment, 2006. 18(4): p. 424.

46. Engelbregt, H., V. Promes and N. Radocz, Handleiding testinstrument Digoloog. Alkmaar: Digoloog, Hogeschool van Amsterdam, 2004.

47. Kerkmeester, M. and J.E. Dek. WMS-IV-NL: Psychometrische eigenschappen. 2014 [cited 2021; Available from: https://www.pearsonclinical.nl/med ia/whitepapers/Whitepaper_WMSIV deel2.pdf.

48. Kaldenbach, Y. 15-Woorden Test Scorehulp Kaldenbach. 2017 [cited 2021 11-11-2021]; Available from: https://www.apollopraktijk.nl/Overi ge $\% 20$ tests bestanden $/ 15 \mathrm{WT} \% 20 \mathrm{~S}$ corehulp $\% 20$ Kaldenbach $\% 20$ \%20informatie.pdf.

49. WAIS-IV-NL: Theoretisch model en aanpassingen ten opzichte van de WAIS III-NL. 2012: Pearson.

50. Brand, N. SDMT: Symbol Digits Modalities Test. 2018 [cited 2021 11-11-2021]; Available from: https://www.mindsware.nl/en/?s=sy mbool.

51. Cohen, J., Statistical Power Analysis for the Behavioral Sciences. 2 ed. 1988, Hillsdale, NJ: Lawrence Erlbaum Associates, Publishers. 